\title{
THE ROLE OF GOVERNMENT IN RESTORING INTERNATIONAL COMPETITIVENESS: THE CASE OF CRISIS MANAGEMENT IN THE BALTIC STATES ECONOMIES VERSUS POLAND ECONOMIES
}

\author{
Anna Matysek-Jędrych \\ Poznan University of Economics, Poland
}

\begin{abstract}
This paper focuses on the relationship between the government actions, global economic crisis, and competitiveness on a national and regional dimension. The Baltic States (i.e., Estonia, Latvia, and Lithuania) have experienced one of the biggest Gross Domestic Product (GDP) contractions during the Global Crisis so far. Meanwhile, Poland was the only country with a positive GDP growth in the European Union during the Global Crisis. Hence, identifying and assessing changes in the relative competitiveness, as a consequence of the economic downturn in both Baltic States and Poland, has sparked many interests.

The main channel through which the crisis undermined competitiveness has been the macroeconomic situation. That is why employing single macroeconomic variables as proxies of competitiveness suggests a much stronger influence of the crisis on competitiveness in comparison to overall measures (e.g. Global Competitiveness Index). It may be generally concluded that a short-term crisis, even if severe, does not have a negative influence on international competitiveness as long as a proper anti-crisis policy is implemented and the country is small enough to react fast and adapt to new conditions in the global environment.
\end{abstract}

Keywords: Baltic States, competitiveness, crisis management, economic policy, Estonia, financial crisis, government policy, Latvia, Lithuania, Poland

\section{INTRODUCTION}

The Global Crisis has affected different aspects of the global economy. Regions, countries, corporations, and households have been hit by unexpected, dramatic and unprecedented events. These events have initially taken place in the financial markets and then in the real economy. Much has been written about the causes, symptoms, and consequences of this crisis (Shiller, 2008; Acharya \& Richardson, 2009; Taylor, 2009; Mayes, Pringle \& Taylor, 2009; Gorton, 2010; Roubini \& Mihm, 2010; Szyszka, 2011; Friedman \& Posner, 2011; Mundell, 2011). This paper aims at contributing to this broad and multifaceted discussion by concentrating on the impact of the crisis management policy (or mismanagement) realized by the government and central bank on the competitiveness of the business environment.

A main goal of this paper is to identify and assess changes in the relative competitiveness of three Baltic States (i.e., Estonia, Latvia and Lithuania) and Poland; first, in consequence of the Global Crisis and second, in consequence of anti-crisis policy implementation in the Baltic States. This paper is organized into five sections. The first section provides a brief presentation of the conceptual background with regards to competitiveness. The second section discusses basic similarities and differences of four Central and Eastern Europe (CEE) economies (i.e., Baltic States and Poland). The third section provides an overview of the crisis management policy in the Baltic States. The fourth section presents and discusses the results of comparative analysis in the field of economic measures of competitiveness and the descriptive competitiveness measure of the Baltic States in comparison to Poland in 2006-2013 (i.e. Global Competitiveness Index). The fifth section provides a conclusion.

\section{CONCEPTUAL BACKGROUND COMPETITIVENESS}

The assessment of the crisis impact on competitiveness should be preceded by an indication of what is meant by competitiveness in this paper. There is no unique definition of this term and the concept seems to be elusive. Taking into account a few of the different concepts of competitiveness (Fajnzylber, 1988; Maarten de Vet, 1993; Fanelli \& Medhora, 2002; Garelli, 2006), we can broadly define it as the ability of an element of $a$ general environment (a company, a cluster, a region, a country or a group of countries, etc.) to operate efficiently and productively in relation to other similar elements of this environment. However, the question of how to measure this ability still remains under investigation. For example, the World Economic Forum (WEF, 2007) uses the annual changes in GDP per capita 
as such a measure. The official definition of the OECD of a nation's competitiveness is as follows: "the degree to which a country can, under free and fair market conditions, produce goods and services which meet the test of international markets, while simultaneously maintaining and expanding the real incomes of its people over the long term" (Maarten de Vet, 1993, p.26).

According to Kowalski and Pietrzykowski (2010), the assessment of a country's competitiveness can be conducted by the means of two different approaches:

1. The comparative dynamic analysis of economic indicators, identified in economic literature as the proxies of the country's competitiveness (Durand \& Giorno, 1987; Turner \& Van'tdack, 1993; Fagerberg, Knell \& Srholec, 2004).

2. The comparative dynamic analysis of composite competitiveness measures, which were created by using many quantitative (statistical) and qualitative (perception of the economy and business environment) data, distinguishes given economies and aggregates them into one measure of performance (e.g. from the World Economic Forum, Global Competitiveness Index, and International Institute for Management Development)

Both of these approaches were used by this researcher to assess changes in the relative competitiveness of three Baltic States and Poland in the face of the Global Crisis.

\section{THE BALTIC STATES VS. POLAND}

The Baltic States are not identical; they differ slightly in the structure of their economy, the extent of their fiscal and external balances, and their tendencies toward internal policy. On the other hand, they share a number of structural, institutional, and political features and they can be treated as a region. Moreover, the Baltic States can all be characterized as small, relatively open, and democratic economies. In comparison, Poland can be characterized as a large, less open, and democratic economy, particularly when taking into account both the GDP volume and the population. The country's economic structure and basic features are also different. In fact, Poland is dominated in structure by production and services, with a much larger sector of agriculture in comparison to the Baltic States.

Another comparison with Poland reveals that all three Baltic States enjoyed credit-driven booms prior to the financial crisis. In addition, foreign currency denominated indebtedness (e.g., for both households and businesses ) was extremely high in the Baltic States. For example, the share of foreign currency loans in total lending was close to $70 \%$ in Lithuania and close to $90 \%$ in both Estonia and Latvia in 2008 (Koyama, 2010). What are also crucial for these countries are their history and their Soviet heritage which have significantly influenced the shape of their contemporary economies.
Estonia, Latvia, and Lithuania, as well as Poland, have successfully passed the process of transition to democratic political systems with fully functioning market-based economies. This process was reinforced in 2004 after these countries joined the European Union (Bulmer \& Lequesne, 2005; Buiter \& Sibert, 2006). In opposition to Poland, all three countries (Estonia, Latvia and Lithuania) wanted to adopt the euro as soon as possible, which was natural as their national currencies were already tied to the euro with existing currency boards. When adopting the fixed exchange rate system under the Exchange Rate Mechanism II (ERM II), and abandoning an autonomous monetary policy, the Baltic States experienced huge unanticipated capital inflow and negative consequences as a result of the global crisis. Large imbalances in the Baltic economies, accompanied by: (a) low interest rates adopted from the euro zone as a consequence of ERM II acceptance, (b) credit booms, and (c) a very sharp decrease in economic activity in those countries, revealed weaknesses of the institutional arrangements of the euro area accession process in the face of the crisis (Nyberg, 2009; Ingves, 2010; Lewis, 2011).

The Baltic States, indeed, experienced the largest GDP contraction during the global crisis thus far (IMF 2010), which is the main reason these countries are interesting subjects to study. Comparing relative changes in competitiveness level in these three countries (which have been hit heavily by the crisis) and Poland, seems to be even more interesting.

\section{HOW HAVE THE BALTIC STATES MANAGED THE CRISIS?}

In response to the crisis, the overall policy strategy of the Baltic government was similar in all three countries. In response to the crisis, the Baltic States relied on contractionary fiscal and nominal wage policies; they also stuck to using currency pegs, and embracing austerity (Åslund, 2009).

On a general level, the crisis management policy can be considered as both internally-driven and externallydriven (e.g., initiated by the EU, the IMF, the World Bank or other international institutions). Out of three Baltic States under investigation, Latvia was the only country with a real need of external help (Ābotina, 2011; Bakker \& Klingen, 2012; Kattel \& Raudla, 2012; Mačys, 2012).The help came mainly from the IMF, the European Commission, and Nordic countries. The other two countries (i.e., Estonia and Lithuania) managed to overcome the recession without direct external help (The Economist, 2009b). Therefore, this brief assessment concentrates on only internal aspects of the anti-crisis policy in the Baltic States.

Crisis management in the Baltic States can be described as internal devaluation (Calmfors, 1998; Purfield \& Rosenberg, 2010; Wolf, 2011). The content, sequence, and emphasis differed in details between the 
three countries, but they all concentrated generally on the following four issues:

- Adjustment in nominal wages;

- Fiscal adjustment;

- Preserving stability of the financial system; and

- Repairing balance sheets of both households and private companies.

The Baltic States have a traditionally high labor market flexibility (Masso \& Krillo, 2011), which made both the modification of work contracts and the reduction of the wage level relatively easy to implement. The first tool has been used in the private sector and the second one in the public sector. The fundamental tool of this policy was, in all three cases, an increased downward flexibility of wages-with a decrease of wages by $15-20 \%$ in the public sector. The adjustment in nominal wages was accompanied by programs aiming at the protection of the most vulnerable parts of the population. For example, the access to unemployment benefits was simplified in Latvia and Lithuania; while in Estonia and Lithuania, EU funds were transferred to programs supporting job creations and training. Additionally, the poorest part of society in the Baltic States was protected by guaranteeing a minimum level of income, free access to health care, and the expansion of the social safety net (Bakker \& Klingen, 2012).

In relation to the second element of crisis management, Purfield and Rosenberg (2010) stated that there were at least four goals of sizeable fiscal adjustment: (a) reducing fiscal funding needs, (b) restoring fiscal sustainability, (c) bringing back deficits to the Maastricht fiscal criterion (3\% of GDP) and, d) supporting a correction of the real exchange rate by containing domestic demand growth. The steps taken by the Baltic States' governments contained among others increases in the VAT and corporate profit tax, introduction of new taxes, elimination of some forms of social allowances, and the reduction of personal income tax.

The crisis management objective of great importance was to preserve stability of the financial system. At first, the focus of both governments and central banks was to secure the liquidity position in the commercial banks primarily through the commitments from Scandinavian parent banks. The second stage of crisis management contained the recapitalization of banks; however, authorities also started in-depth regulatory reforms aimed at strengthening both banking supervision and crisis management in the financial system in the future.

The last issue of crisis management policy concentrated on repairing balance sheets of both households and private companies. Due to the traditional low level of interventionism in the Baltic States, the tools for debt restructuring were used mainly by private companies. However, governments in all three countries worked on improving their legal frameworks for out-ofcourt and voluntary debt restructuring processes (Herzberg, 2010).

It may be concluded that the implementation of the crisis management strategy was facilitated by a number of regional factors. The Baltic States economic and political structures had already undergone in-depth reforms, which made them more flexible and easier to adapt to changes in the external environment. The structure of their financial markets, which are fairly small and dominated by a few domestic players, protected the Baltic States from outside speculative attacks. What is also important, the Baltic States cooperated closely with the Nordic countries, mostly through the foreign bank ownership. This cooperation enhanced the stability of the Baltic States' banking sector via the Scandinavian parent banks' willingness and ability to absorb losses (The Economist, 2009a). Finally, social confidence and acceptance of painful reforms were critical factors in the successful crisis management in the Baltic States.

\section{CRISIS AND COMPETITIVENESS OF THE BALTIC STATES VERSUS POLAND: THE PICTURE ACQUIRED FROM THE ECONOMIC INDICATORS}

\section{GDP Growth}

The most comprehensive measures of change in competitiveness in an economic context are GDP (see Figure 1) and GDP per capita dynamics. The economic growth rate in the Baltic States and Poland remained relatively high in 2006 and 2007 (as indicated in Figure 1). Latvia had the highest average of GDP growth rate for two-year period (10.4\% per year), when compared to Estonia's and Lithuania's level which were $8.8 \%$ per year. Poland's average GDP growth rate for the period 2006-2007 was much lower (6.5\%). However, one could observe the real GDP decrease in 2007, in relation to Estonia and Latvia, and then a substantial decrease in GDP in 2008 in the Baltic States. Meanwhile, in Poland the GDP was still positive. In 2009, Estonia, Latvia, and Lithuania recorded a double-digit decrease in their real GDP. The situation in Poland was quite different. Although, in this case one might observe the impact of the crisis, the GDP growth rate was lower but still positive in 2009 . 


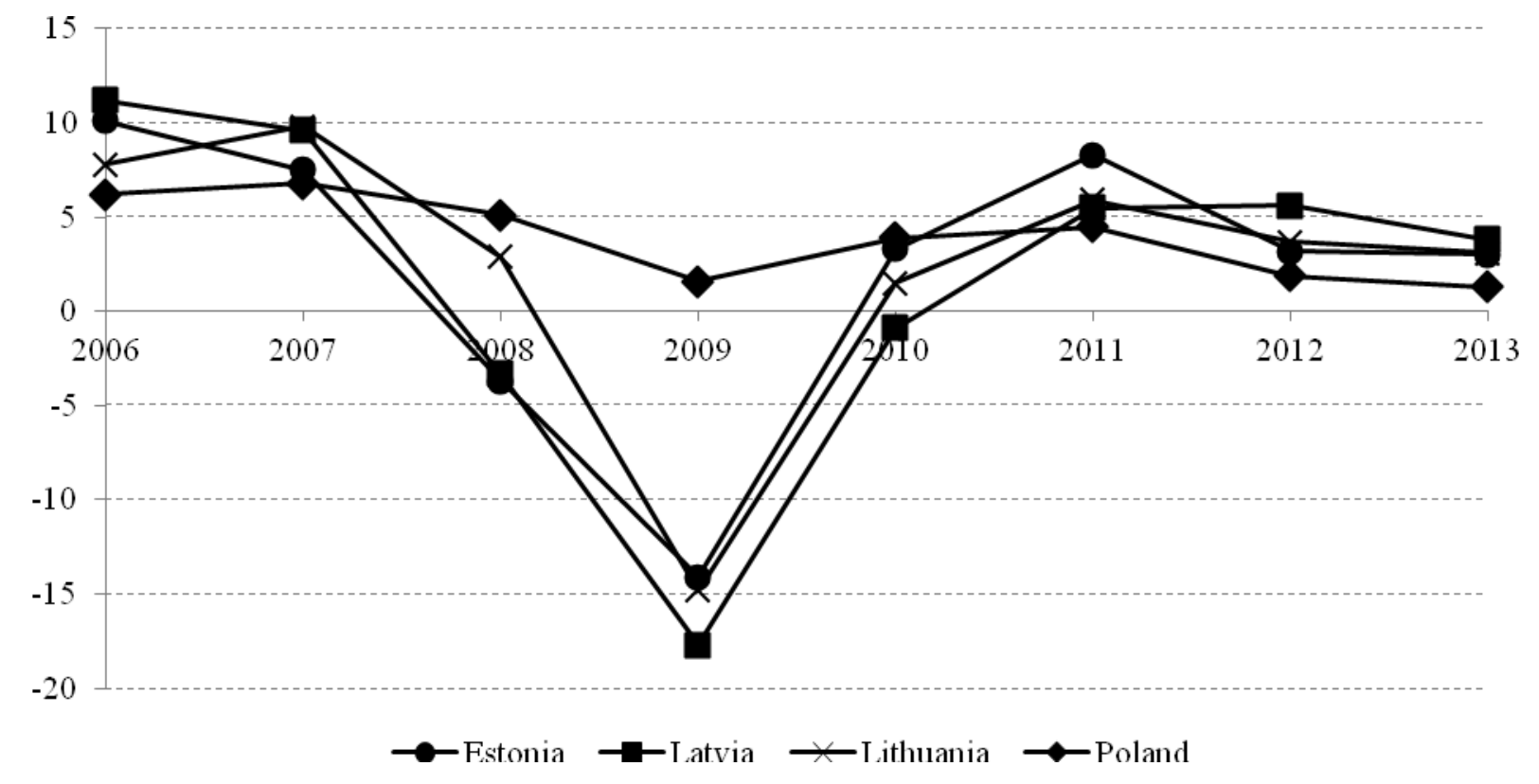

Figure 1. GDP growth rate in the Baltic States and Poland in 2006-2013 (\%, year-to-year)

Source: Own calculation based on Eurostat database 2013.

Lithuania went through the worst correction of GDP in the face of the subprime crisis. Although 2009 proved particularly severe for all three countries, one can note that after the two-year long GDP decrease, the Baltic economies achieved a positive growth rate in 2010. In 2011, Estonia was one of the EU's fastest-growing economies, as reflected in the 2011 level of GDP growth: $8.3 \%$ in Estonia, $5.5 \%$ in Latvia, $5.9 \%$ in Lithuania and $4.5 \%$ in Poland. In 2012, Latvia was surely such a country in the EU, as reflected in the 2012 level of GDP growth: 3.2\% in Estonia, 5.6\% in Latvia, $3.7 \%$ in Lithuania and $1.9 \%$ in Poland. All four countries still have positive, although worse, forecasts for 2013. Taking into account the severity of the crisis in the Baltic States, it needs to be stressed that the period of negative GDP growth rate was very short, lasting only two years.

The impact of the crisis on the Baltic States' competitiveness measured by GDP - and similarly GDP per capita-was extremely severe compared to the Polish economy reaction on the crisis. However, it needs to be highlighted that the tendencies in GDP (and GDP per capita) improved quickly, after only two years of the crisis outbreak, thanks to the consistent policy of crisis management and support from the IMF and the European Commission in Latvia. Thus, it is highly probable that the impact of the crisis on the overall competitiveness of the Baltic States was not as severe as we might have expected while analyzing GDP and GDP per capita tendencies.

\section{Tendencies in Prices and the Labor Market}

The tendencies in GDP growth mentioned above were accompanied by growing inflation as measured by the
HICP, Harmonized Index of Consumer Prices (see Figure 2). While Latvia had a high level of inflation for the whole period before the crisis - the level was above $6.0 \%$ per each year - the HICP growth rate rose in the Baltic States in 2007 and reached its peak in 2008 (e.g., Latvia at $15.3 \%$, Lithuania at $11.1 \%$, and Estonia at $10.6 \%)$. The same tendency of growing inflation from 2006 can be observed in Poland; however, the scale of the tendency is incomparably smaller, with $4.2 \%$ as a peak of inflation in 2008. In all four countries, inflation growth was mainly demand-driven, since it was caused by higher energy and food prices, a shrinking labor supply, and the excessive increase demand, which are the features of overheated economies (NBP, 2007; 2009; ECB, 2010).

Moreover, it should be stressed that the process of falling inflation in relation to the Baltic States started very rapidly in mid-2008 and all three countries recorded a very considerable fall in prices in 2009 as a consequence of the sharp drop in domestic consumption. In January 2009, the inflation measured by HICP amounted to $0.2 \%$ (Estonia), 3.3\% (Latvia), $4.2 \%$ (Lithuania) and $4.0 \%$ (Poland) on a year-to-year basis. The decrease in inflation can be explained mainly by decreases in the prices of food, housing (electricity, gas and heating), and fuels. Additionally, core inflation experienced a significant drop in all three Baltic States. The decrease in core inflation was the consequence of a consistent crisis management policy in the Baltic States, which can be verified by stabilization in the inflation in 2010-2012. As mentioned above, the crisis management tools included among others an increased downward flexibility of wages and prices. While analyzing the impact of the crisis on competitiveness, one may argue that such a short period of growing inflation might not 
be embodied in the worsening overall competitiveness.

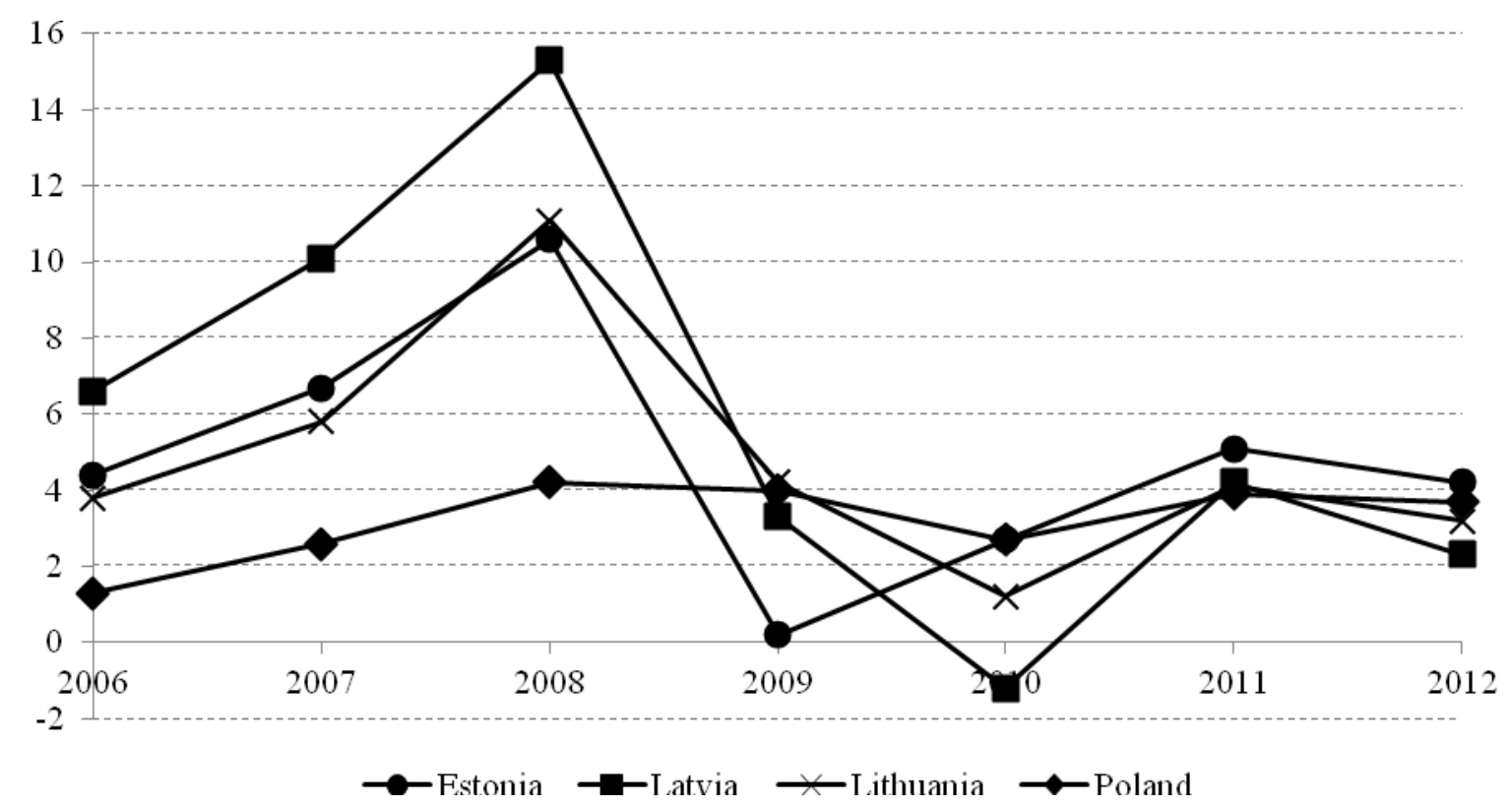

Figure 2. Inflation growth in the Baltic States and Poland in 2006-2012 (HICP, \%, year-to-year) Source: Own calculation based on Eurostat database 2013.

It is also interesting to analyze the labor market reaction to the crisis situation. Labor market tendencies and statistics, especially regarding productivity and costs, are important in the context of the competitiveness of the emerging economy (Turner \& Van'tdack, 1993; Krugman, 1994; Smolny, 2009; Blanchard, Das \& Faraqee, 2010; Pina, 2011).

Thus, from this point of view, it is important to determine how the crisis affected the real costs of labor. The relevant empirical data for Estonia, Latvia,
Lithuania and Poland are shown in Figure 3. From 2006 to 2009, the tendencies in real labor costs were changeable, with short periods of growing and declining costs in all four countries under investigation. A distinct drop in the real labor costs growth rate in 2010 (reaching $-9.5 \%$ in Lithuania, $-8.2 \%$ in Latvia and $-6.6 \%$ in Estonia) and non-appearance of such tendency in Poland, may be perceived as one of the elements that allowed the Baltic States to quickly recover from the global crisis.

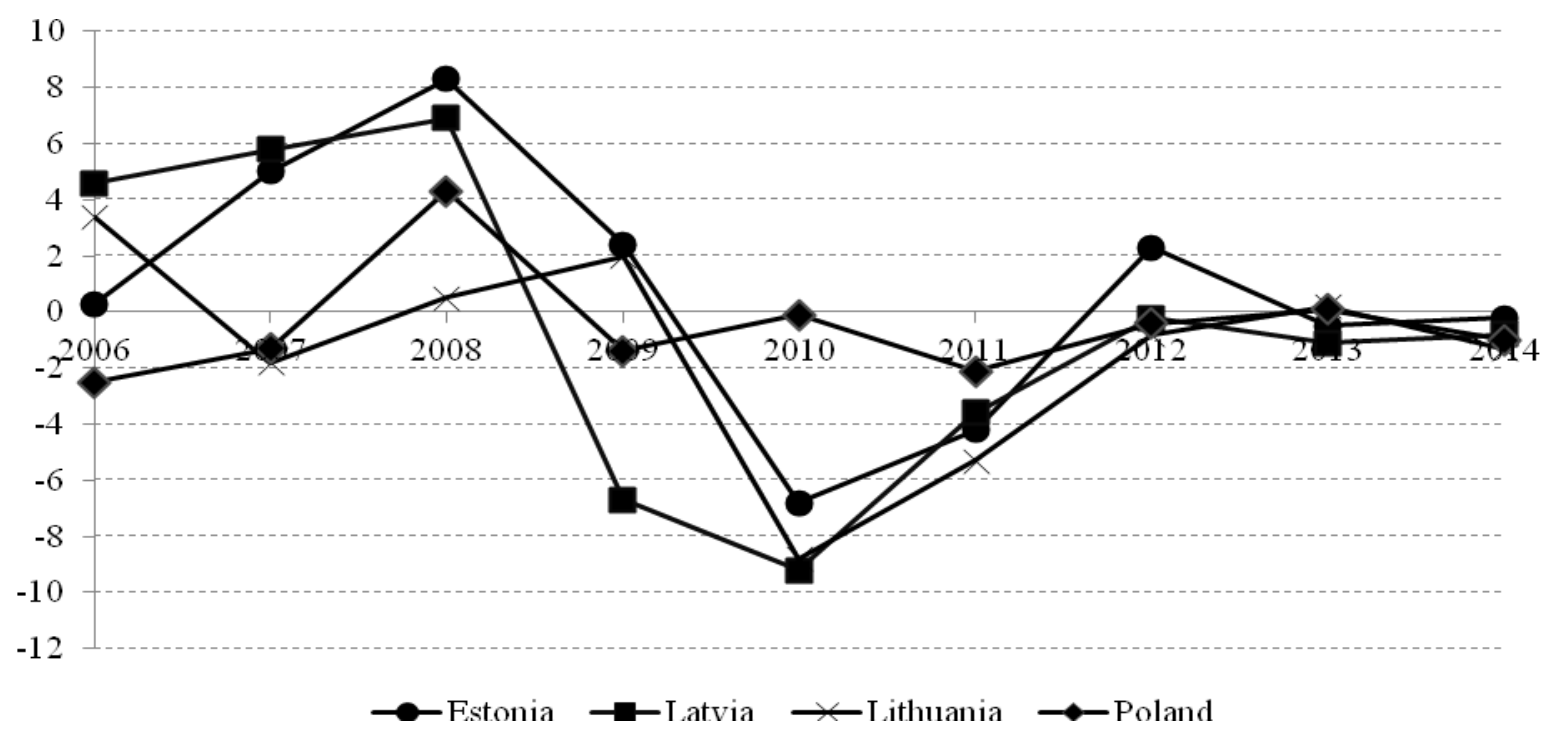

Figure 3. Real unit labor costs growth in the Baltic States and Poland in 2006-2014 (year-to-year) *2013, 2014 - forecast

Source: Own calculation based on Eurostat database 2013. 
Prognostic data also suggest that no fast growth of real labor costs is expected in 2013 and 2014, which, if the efficiency remains unchanged, could not undermine the Baltic region's competitiveness. Therefore, the economic crisis does not seem to have a negative influence on real unit labor costs, and in the next step this is not at all demonstrated by the deterioration of international competitiveness. What is more, this economic variable was a tool successfully used in the process of crisis management and restoring competitiveness. According to Eurostat, the 2012Latvian labor costs per hour were a quarter of those of the eurozone as a whole and the Estonia and Lithuania record level just a little higher than Latvia.

Another variable describing the labor market is labor productivity, which is of key importance for international competitiveness. At first, it needed to be stressed that the average level of labor productivity per person employed in the Baltic States and in Poland was slightly below or above $50 \%$ of the average EU-27 level in 2006 (in Latvia $-48.8 \%$, in Lithuania $-56.7 \%$, in Poland $-61.0 \%$ and in Estonia $-62.3 \%$ ). The situation has changed between 2006-2012, and we can observe improvement in productivity for 2012 in all four countries $(64.1 \%, 68.7 \%, 72.1 \%$ and $72.2 \%$ of the EU27 average level in Latvia, Estonia, Lithuania and Poland respectively). According to data presented in Figure 4, the 2006-2012 (2006-2010 for Estonia) period was characterized by a relatively stable growth of this factor; however, with variable growth rate in particular countries (e.g., about 12.1\%, 9.6\%, 7.5\% and 3.8\% each year in respectively Latvia, Lithuania, Poland and Estonia), there were only occasional disruptions of this trend. Both disruptions may be perceived as the result of the subprime crisis that occurred in Estonia (in 20072008) and Lithuania (in 2008-2009). The tendency in Poland, in the whole analyzed period, was the most stable but it was much slower comparing to Latvian and Lithuanian cases.

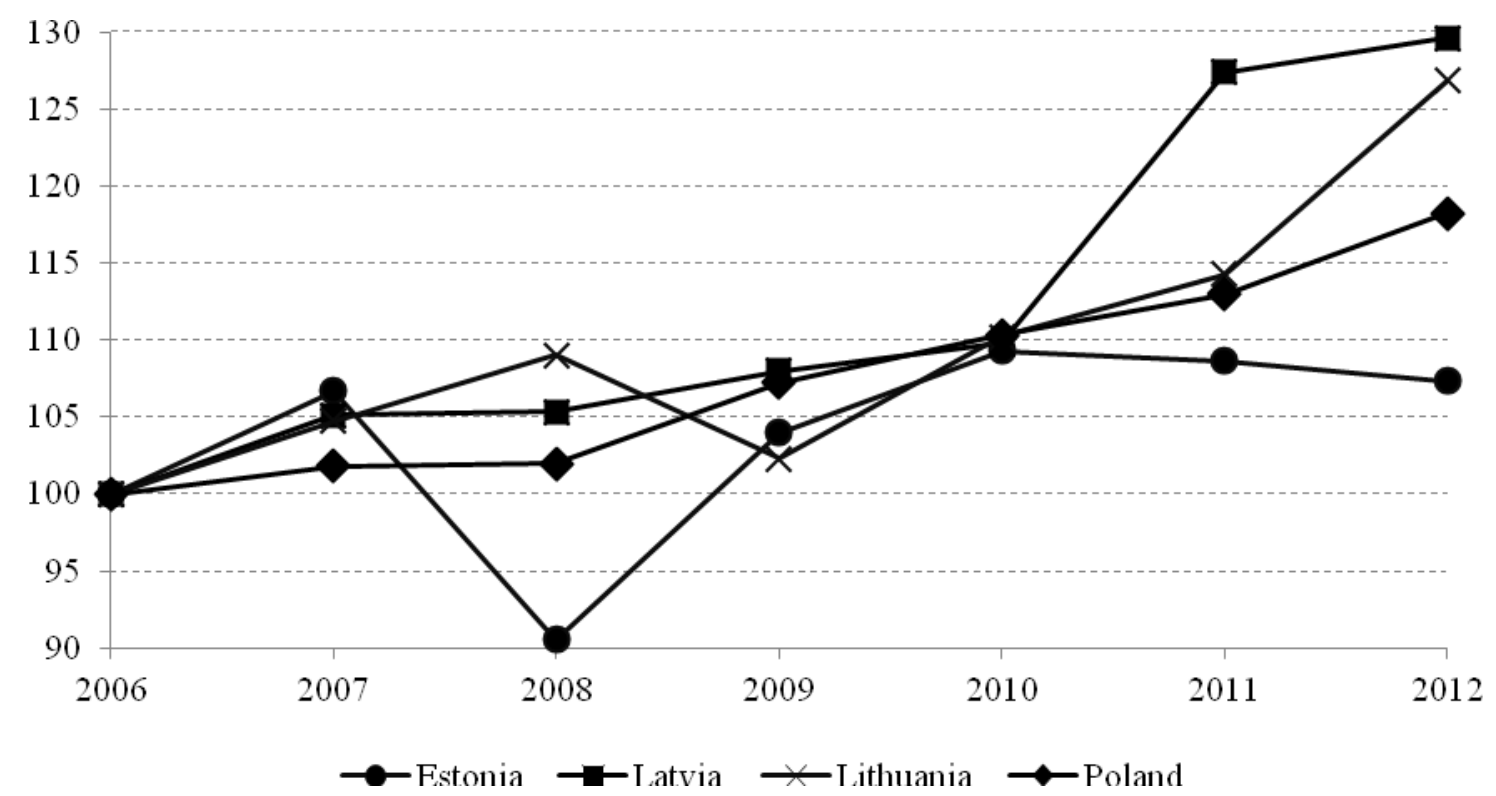

Figure 4. Labor productivity in the three Baltic States and Poland in 2006-2012 (2006 = 100) Source: Own calculation based on Eurostat database 2013.

What is particularly significant in the context of the analysis is that the drop in labor productivity, although severe, might not have affected the broadly defined realm of competitiveness due to its briefness and largely unique features of the labor market that were present at that time in the Baltic States-especially in Estonia where labor productivity fell greatly below the 2006 level.

\section{External Trade and Competitiveness}

With regards to GDP volume, the Baltic States may be regarded as relatively small and open while Poland is regarded as bigger, and thus, less open. Therefore, the vital aspect of the assessment of open countries competitiveness is the individual country's position in the field of international trade. Competitiveness of all four countries has been expressed through the variable of exports as a percentage of GDP (see Figure 5).

The collapse of global trade severely impacted the Baltic States, mostly because some of their primary trading partners (e.g., Russia and the Scandinavian countries) were also hard hit by the crisis. The country that had the highest trade exposure was Estonia, in which exports accounted for $72.7 \%$ of its GDP in 2006 and $91.6 \%$ in 2013. In the other two Baltic States, the channel of international trade seemed less material in transferring the financial crisis. For example, the exports in Lithuania accounted for $59.1 \%$ of GDP in 
2006 and $85.7 \%$ of GDP in 2013; in Latvia they accounted for $45.1 \%$ of GDP in 2006 and $61.7 \%$ of GDP in 2013. Poland's level of foreign trade exposure, expressed by exports as a percentage of GDP, is considerably lower (e.g., exports accounted for $40.4 \%$ of its GDP in 2006 and $48.5 \%$ in 2013 . Thus the risk of transferring the financial crisis was relatively low during the whole analyzed period

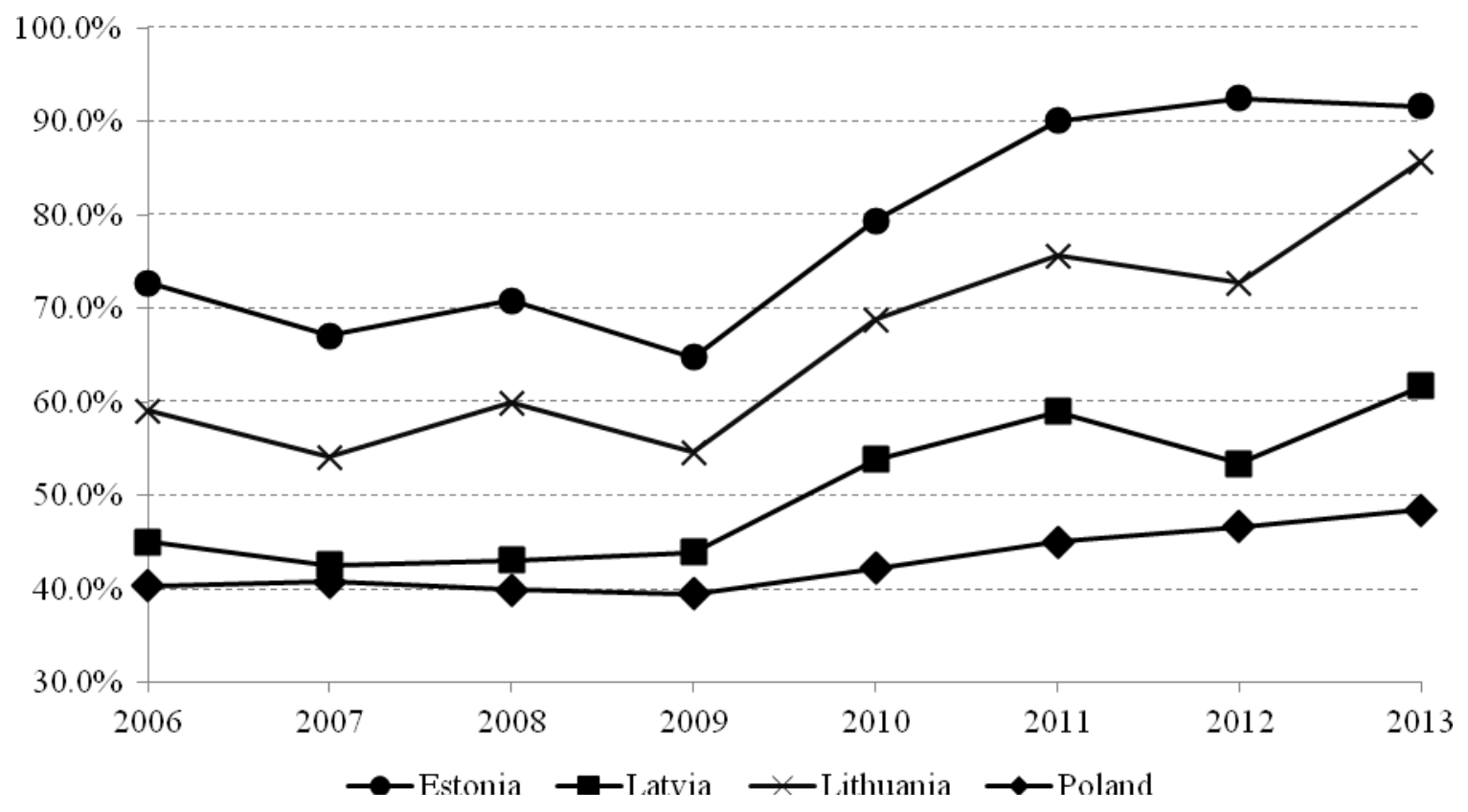

Figure 5. Export of goods and services in the Baltic States and Poland as \% of GDP in 2006-2013 (year-to-year) Source: Own calculation based on Eurostat database 2013.

In 2006-2009 (i.e., the period of recession), the value of the discussed index remained relatively stable in all four countries, with extremes amounting to respectively $67.1 \%$ and $77.7 \%$ for Estonia, $42.5 \%$ and $48.2 \%$ for Latvia, $54.1 \%$ and $59.9 \%$ for Lithuania, and $39.4 \%$ and $40.8 \%$ for Poland. However, it should be emphasized that this stability was due, among other factors, to a strong drop in GDP during the recession in the Baltic States. On the other hand, the significant growth of the index in 2010-2013, in relation to the Baltic States, resulted from the higher growth of exports than of GDP. Moreover, in all three cases the increase in 2011 was above 30 percentage points in relation to the 2010 level.

The analysis of uniform performance measures in the three Baltic States, in comparison to the same measure in Poland during the economic downturn, created the foundation for concluding that the global crisis affected these three Baltic economies in a similar way. As a consequence of the euro adoption process, all three Baltic States had sufficiently balanced budgets and low public debts before the crisis began. Additionally, ERM II rules made it very difficult, and sometimes impossible, to use the exchange rate as a tool of crisis management policy. Similar features of the Baltic States economies, as well as institutional arrangements in the euro adoption process and the manner in which the crisis affected these economies, caused the application of a similar crisis management policy. Another important conclusion is that the Polish economy has not been affected by the crisis at all. The only visible signal of global crisis in Poland was the slightly decrease in GDP growth rate in 2009. As described previously, we might expect similar tendencies in international competitiveness in the four analyzed countries.

\section{CRISIS AND COMPETITIVENESS OF THE BALTIC STATES: HOW DIFFERENT IS THE OVERALL PICTURE?}

Based on the conducted analysis discussed in the previous section, it should be acknowledged, beyond doubt, that the economic crisis strongly affected the competitiveness of the Baltic economies in comparison to Poland, which is clearly demonstrated by individual macroeconomic variables. At the same time, this influence was short-lived in the case of the Baltic States. This provokes important questions: Was such a brief crisis, despite its severity, reflected in the overall measures of competitiveness? Should such a crisis be a basis for critical business decisions (e.g. a background for exit strategy)? Should the impact of the crisis on the business environment be assessed by analyzing economic indicators, as shown in the above section, or is the broader context of analysis much more adequate? Based on the comparison between the Baltic States and 
Poland, how different are tendencies in competitiveness in crisis and non-crisis countries?

The measurement methodology of general competitiveness, employed by WEF, is based primarily on the perception of changes in selected aspects of the economic, social, and business environment. The Global Competitiveness Index, proposed by WEF, captures open-ended dimensions of competitiveness by providing a weighted average of many different components. Each dimension reflects one aspect of the complex reality referred to as competitiveness. WEF groups all of these components into 12 pillars of competitiveness. Moreover, each pillar is characterized by over a dozen specific variables. Note: due to a large number of factors and the possibility of the obliteration of tendencies, the charts in figures 6 through 9 involve only selected pillars of competitiveness. The data for the least unchanged variables, as measured by the standard deviation in the hyphen between 2006-2012 should be longer.

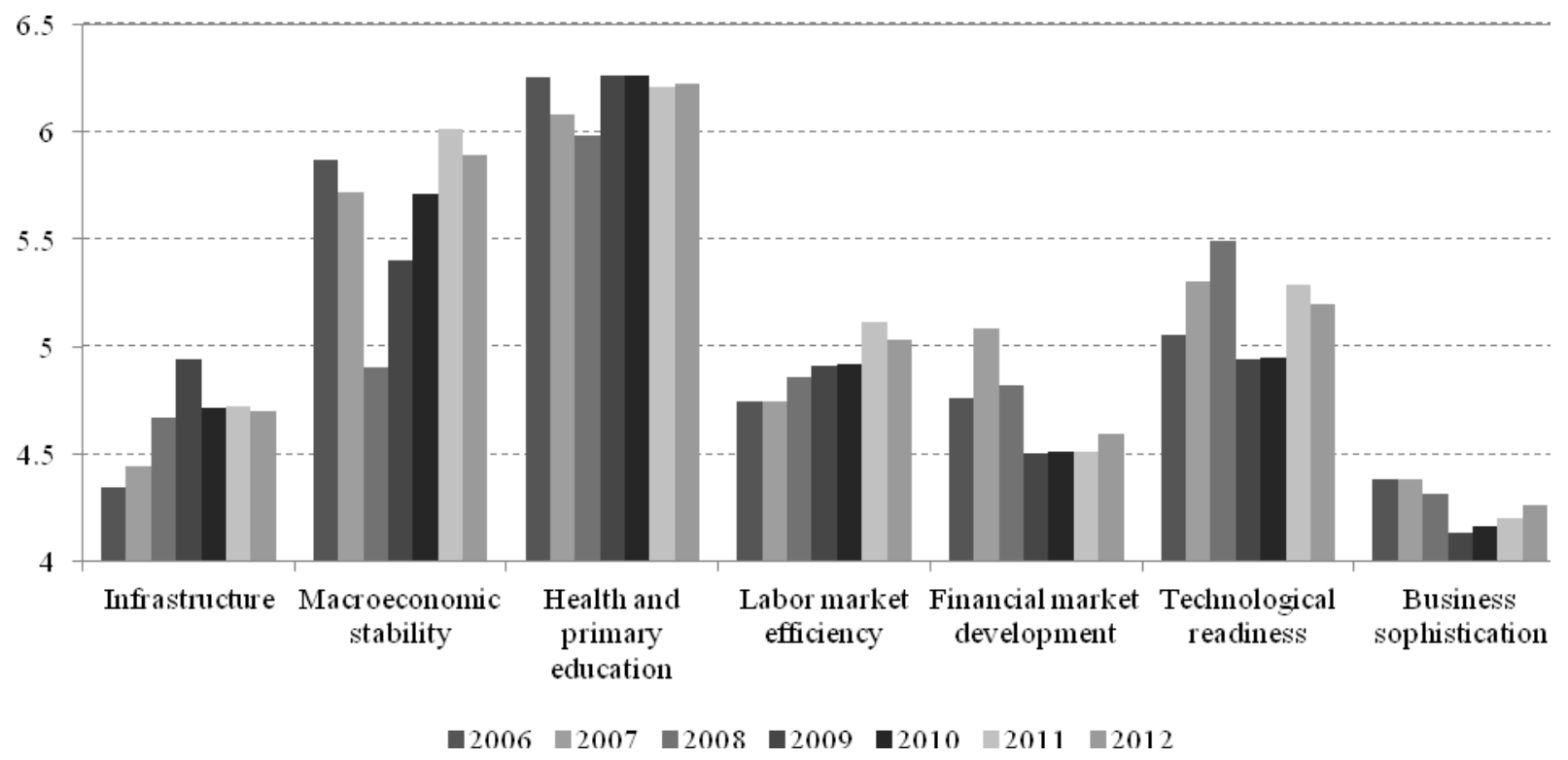

Figure 6. GCI - comparative dynamic performance of Estonia in 2006-2012

Source: Own calculation based on WEF $(2007 ; 2008 ; 2009 ; 2010 ; 2011 ; 2012 ; 2013)$.

Figure 6 illustrates dynamic changes in the competitiveness of the Estonian economy in 2006-2011. The influence of the crisis on the perception of competitiveness is only noticeable in two aspects: macroeconomic stability and health and primary education (with a drop in average values in 2008 comparing with 2006 by 0.97 and 0.62 , respectively). As far as the financial aspect of competitiveness is concerned, the crisis materialized with a certain delay (with a drop in financial market sophistication in 2009 comparing with 2006 by 0.58 and then stabilization at the lower level in 2010 and 2011). Other variables describing the Estonian economy remained almost unchanged (deviating by a maximum of 0.25 point over the whole period under study) or improved (particularly infrastructure - with an increase in 2012 comparing with 2006 by 0.36 and labor market efficiency - an increase in 2012 comparing with 2006 by 0.29 ).

A similar situation occurred in the Latvian economy. It should be stressed that this economy has, on average, poorer competitiveness than Estonia in all the studied dimensions.

Nevertheless, the crisis has only affected Latvian economic competitiveness by undermining its macroeconomic stability and health and primary education (with a drop in average values in 2008 comparing with 2006 by 1.24 and 0.43 , respectively). The deterioration of the financial (financial market sophistication, drop in 2009 comparing with 2006 by 0.84 ) and business (business sophistication, drop in 2009 comparing with 2006 by 0.57 ) aspect came to Latvia with a delay, just like in Estonia. Other variables describing the Latvian economy remained almost unchanged (deviating by a maximum of 0.3 points over the whole period under study) or improved (particularly technological readiness - with an increase in 2012 comparing with 2006 by 0.83 , and infrastructure - an increase in 2012 comparing with 2006 by 0.39 ).

In Lithuania, the influence of the crisis on economic competitiveness was similar, if not more severe (see Figure 8). The drop in competitiveness was again demonstrated by lower values of macroeconomic stability and health and primary education, but the scale of deterioration was much bigger than in the other two cases (with a drop in average values in 2009 comparing with 2006 by 1.06 and 1.24 , respectively). On the other hand, the perception of the financial environment competitiveness (financial market sophistication, with a drop in 2010 by 0.5 ) in Lithuania suffered a milder blow, although with a year-long delay. Other variables 
describing the Lithuanian economy remained almost unchanged over the whole examined period or improved (particularly technological readiness - with an increase in 2012 comparing with 2006 by 1.02 , and infrastructure - increase in 2012 comparing with 2006 by 0.65$)$.

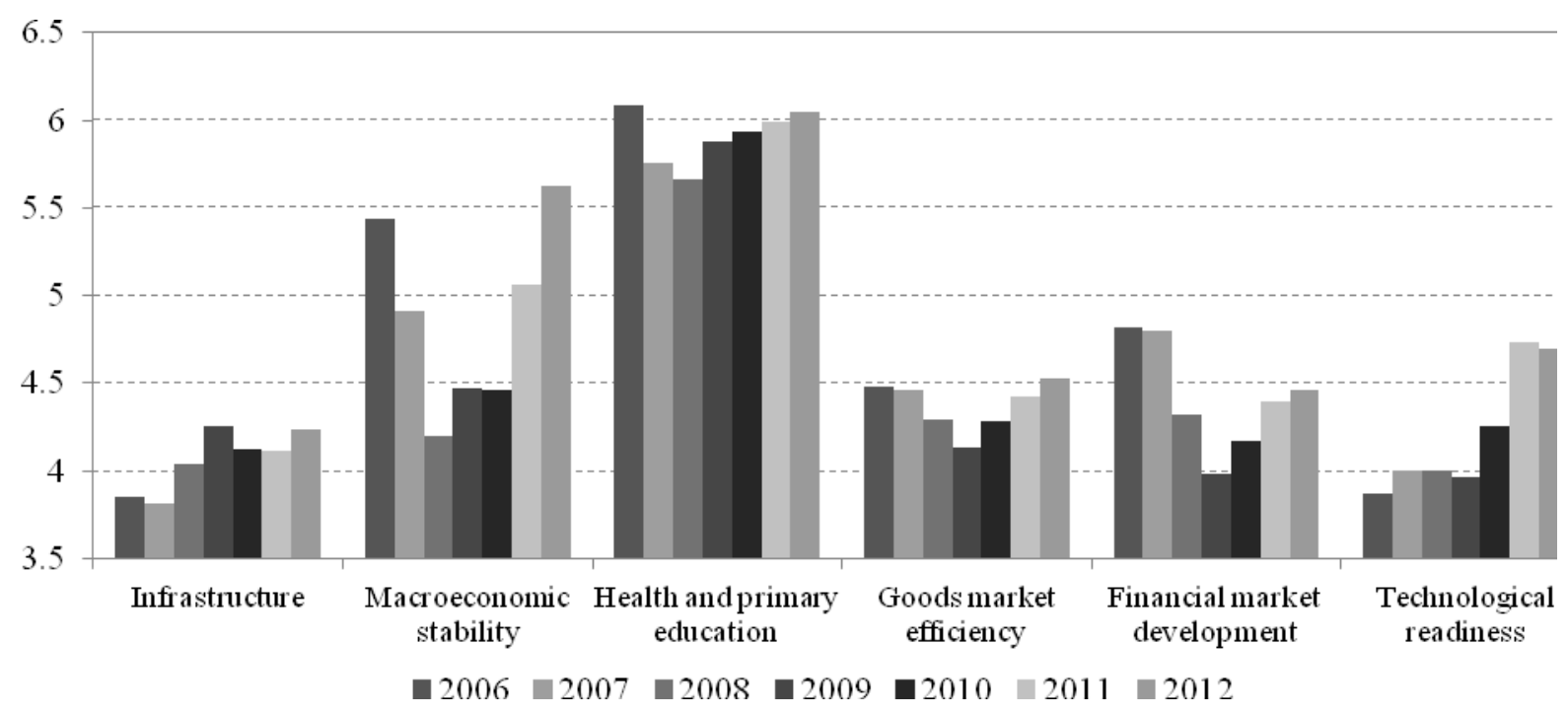

Figure 7. GCI - comparative dynamic performance of Latvia in 2006-2012

Source: Own calculation based on $\operatorname{WEF}(2007 ; 2008 ; 2009 ; 2010 ; 2011 ; 2012 ; 2013)$.

In Poland, the influence of the crisis on the international competitiveness is hardly to observe (see Figure 9). In case of most analyzed factors of competitiveness, one can conclude, that there was a relatively stable increase of index value during the crisis period (i.e. between 2006 and 2009). The only one visible drop in competitiveness was again demonstrated by lower value of macroeconomic stability. Although

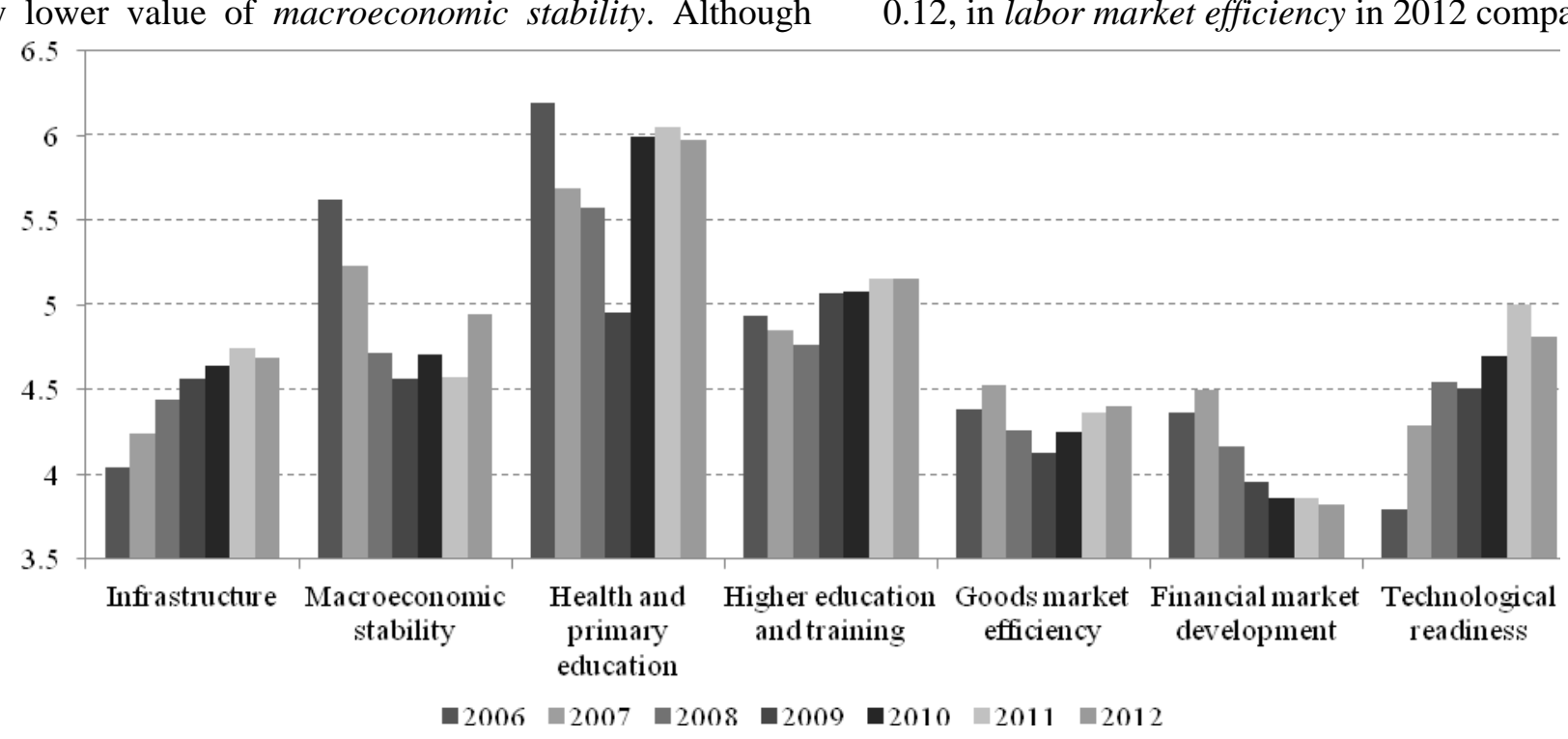

the scale of deterioration was significant (with a drop in average values in 2008 comparing with 2007 by 0.69 ), it seems that it was just a one-time change. As far as the financial and business aspects of competitiveness are concerned, the crisis materialized with a certain delay and just slightly (with a drop in financial market sophistication in 2012 comparing with the 2009 peak by 0.12 , in labor market efficiency in 2012 comparing with

Figure 8. GCI - comparative dynamic performance of Lithuania in 2006-2012

Source: Own calculation based on WEF $(2007 ; 2008 ; 2009 ; 2010 ; 2011 ; 2012 ; 2013)$.

the 2009 peak by 0.38 and in business sophistication in 2010 comparing to 2008 by 0.29 and then stabilization at the lower level in 2011 and 2012). Other variables describing the Polish economy remained almost unchanged or improved during the period 2006-2012 (particularly technological readiness - with an increase 
competitiveness, one can conclude, that there was a relatively stable increase of index value during the crisis period (i.e. between 2006 and 2009). The only one visible drop in competitiveness was again demonstrated by lower value of macroeconomic stability. Although the scale of deterioration was significant (with a drop in average values in 2008 comparing with 2007 by 0.69 ), it seems that it was just a one-time change. As far as the financial and business aspects of competitiveness are concerned, the crisis materialized with a certain delay and just slightly (with a drop in financial market sophistication in 2012 comparing with the 2009 peak by 0.12 , in labor market efficiency in 2012 comparing with the 2009 peak by 0.38 and in business sophistication in 2010 comparing to 2008 by 0.29 and then stabilization at the lower level in 2011 and 2012). Other variables describing the Polish economy remained almost unchanged or improved during the period 2006-2012 (particularly technological readiness - with an increase in 2012 comparing with 2006 by 1.03 , and infrastructure - increase in 2012 comparing with 2006 by 0.93$)$.

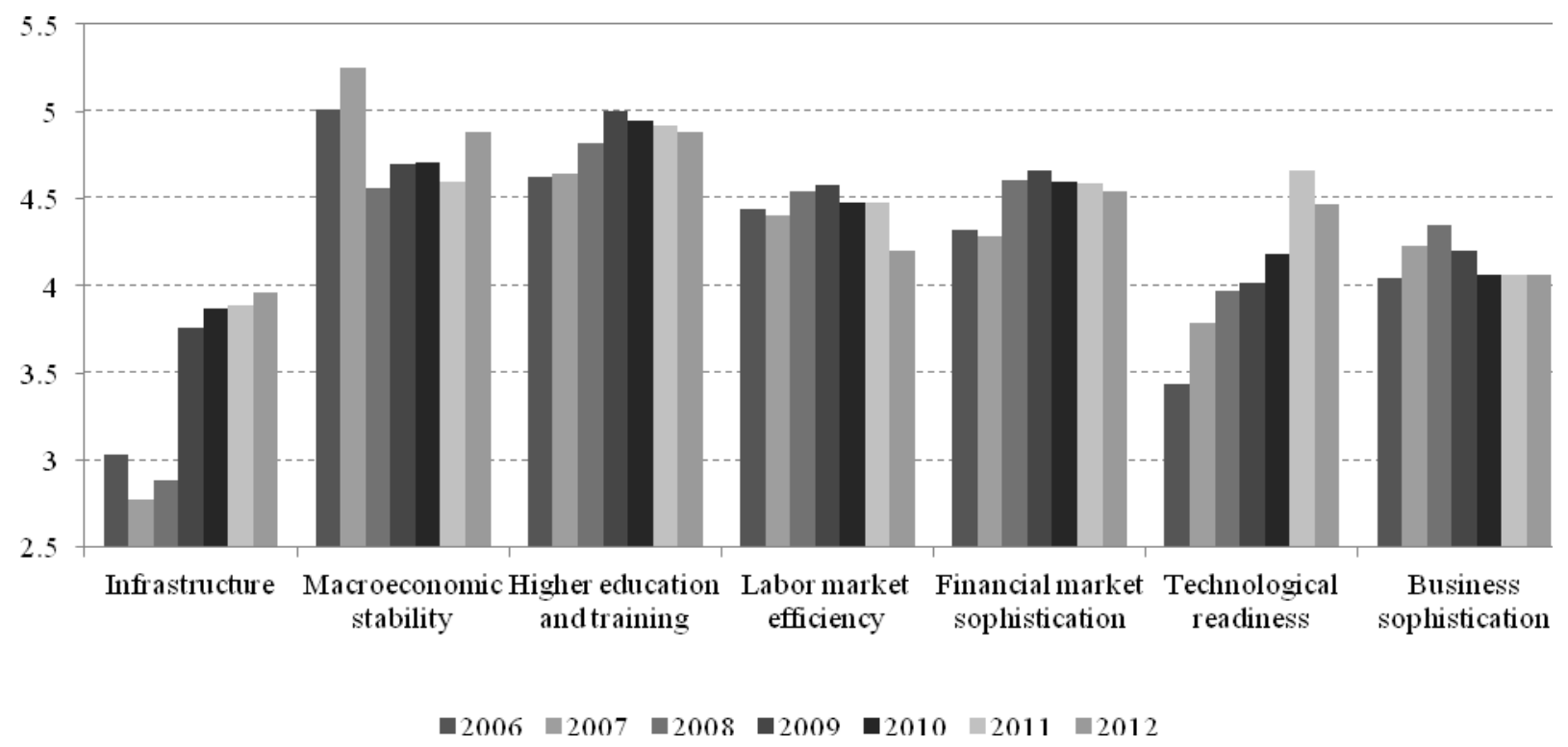

Figure 9. GCI - comparative dynamic performance of Poland in 2006-2012 Source: Own calculation based on WEF $(2007 ; 2008 ; 2009 ; 2010 ; 2011 ; 2012 ; 2013)$.

In general, it may be stated that in all the analyzed countries there was a similar mechanism of reaction of the international competitiveness to the economic crisis. It was demonstrated primarily in the deterioration of the broadly defined macroeconomic situation (i.e., macroeconomic stability), but also in poorer healthcare and education on the basic level (i.e., health and primary education).

\section{CONCLUSION}

The international competitiveness and economic crisis intermingle with one another. The international cases selected for the purpose of this research (i.e., Estonia, Latvia, Lithuania and Poland) were to demonstrate clear and unquestionable evidence that crisis affects the international competitiveness of countries. One may believe that such a deep and painful financial and economic crisis as the current one, in the case of the Baltic States, has to leave some permanent and explicit traces on a country's competitiveness. Thus, the results of this research may surprise a little.

When assessing the impact of the economic crisis on the competitiveness of the Baltic economies and Poland, one may discover some regularities. Firstly, the choice of measures of competitiveness, which provide the basis for analysis, is of key importance to the conclusions formed. Employing single macroeconomic variables suggests a much stronger influence of the crisis on competitiveness, especially in the case countries, which have been hardly hit by the crisis, in comparison to the general measures used by the World Economic Forum. However, it might be possible that the influence of the crisis on competitiveness, though certainly present and quite strong, was too short-lived to considerably affect the measures of competitiveness, which were constructed mainly on the basis of the perceptions and opinions of various social and business groups. Having analyzed individual measures of competitiveness (i.e., macroeconomic indices), it may be concluded that the Baltic States did suffer from economic deterioration for one or two years (i.e., mostly in 2008-2009) in comparison to Poland where economic and business environment was only slightly affected by the crisis. However, efficient counteraction against negative economic trends was the main factor preventing the crisis from affecting other aspects of their competitiveness.

Secondly, the main channel through which the crisis undermined competitiveness was macroeconomic 
stability - with a deterioration of the main macroeconomic indices of the Baltic economies. What is particularly noteworthy is that the crisis essentially did not negatively affect competitiveness through the labor market and commodities market. The efficiency of these markets remained unchanged. Similar trends were displayed by two other important variables determining competitiveness (i.e. infrastructure, innovation and technological readiness).

On the basis of the above considerations, it may be generally concluded that a short-term crisis, even if severe, does not have a negative influence on international competitiveness as long as a proper anticrisis policy is implemented. Sharing a number of structural, institutional, and performance features caused that the crisis undermined the competitiveness of the Baltic States in a similar manner. This, in turn, caused the application of an analogue crisis management policy with the fundamental tool of fiscal policy tightening by an increased downward flexibility of wages and prices.

\section{REFERENCES}

Ābotina, S. (2011). Stability, partnership, responsibility - Latvia's way out of the global financial crisis. Baltic Rim Economies, 1, February 28, 1-2.

Acharya, V.V. \& Richardson, M. (2009). Restoring Financial Stability. How to Repair a Failed System. New York: Wiley Finance.

Åslund, A. (2009). The East European Financial Crisis. CASE Network Studies \& Analyses, 395.

Bakker, B.B \& Klingen, C. (2012). How Emerging Europe Came Through the 2008/09 Crisis. Washington, D.C.: International Monetary Fund.

Blanchard, O.J., Das, M. \& Faraqee, H. (2010). The Initial Impact of the Crisis on Emerging Market Countries. (pp. 263-324). In: Romer, D. \& Wolfers, J. (Eds.), Brooking Papers on Economic Activity. Washington, D.C.: The Brooking Institution.

Buiter, W.H. \& Sibert, A.C. (2006). Eurozone entry of new EU Member States from Central Europe: should they? Could they? National Bureau of Economic Research, from http://www.nber.org/ wbuiter/eurozone.pdf

Bulmer, S. \& Lequesne, Ch. (2005). The Member States of the European Union. Oxford: Oxford University Press.

Calmfors, L. (1998). Macroeconomic policy, wage setting, and employment - what difference does the EMU make? Oxford Review of Economic Policy, 14 (3), 125151.

Durand, M. \& Giorno, C. (1987). Indicators of International Competitiveness: Conceptual Aspects and Evaluation. OECD Economic Studies, 9 (Autumn), 147182. $14^{\text {th }}$

The Economist. (2009a). No panic, just gloom, May

The Economist. (2009b). Baltic martyrs for the euro, July $2^{\text {nd }}$.

ECB (2010). Convergence Report, Frankfurt am Main: European Central Bank.

Fagerberg, J.E., Knell, M.S. \& Srholec, M. (2004). The competitiveness of nations: economic growth in the ECE region. Economic Survey of Europe, 2, 51-66.

Fajnzylber, F. (1988). International competitiveness: agreed goal, hard task. CEPAL Review, 36, 7-23.

Fanelli, J.M. \& Medhora, R. (2002). Finance and competitiveness: framework and synthesis. In J.M. Fanelli \& R. Medhora (Eds.), Finance and Competitiveness in Developing Countries. Ottawa: Routledge.

Friedman, J. \& Posner, R.A. (2011). What Caused the Financial Crisis. Philadelphia: University of Pennsylvania Press.

Garelli, S. (2006). Competitiveness of nations: the fundamentals. In IMD Competitiveness Yearbook. Lausanne: International Institute for Management Development.

Gorton, G.B. (2010). Slapped by the Invisible Hand. The Panic of 2007, Oxford: Oxford University Press.

Herzberg, V. (2010). Assessing the Risk of Private Sector Debt Overhang in the Baltic States. IMF Working Paper, 250, Washington D.C.: International Monetary Fund.

IMF (2010). World Economic Outlook. October, Washington, D.C.: International Monetary Fund.

Ingves, S. (2010). The crisis in the Baltic - the Riksbank's measures, assessments and lessons learned. BIS Review, 11.

Kattel, R. \& Raudla, R. (2012). Austerity that never was? The Baltic States and the crisis. Policy Note, 5, Levy Economics Institute of Bard College.

Kowalski, T. \& Pietrzykowski, M. (2010). The economic and monetary union vs. shift in competitiveness of member states. In B. Jankowska, T. Kowalski, \& M. Pietrzykowski (Eds.), Dimensions of Competitiveness. Poznan: Poznan University of Economics.

Koyama, Y. (2010). Economic Crisis in New EU Member States in Central and Eastern Europe: Focusing on Baltic States. Romanian Economic and Business Review, 5(3), 31-55.

Krugman, P. (1994). Competitiveness: a dangerous obsession. Foreign Affairs, March/ April, 28-44.

Lewis, J. (2010). How has the financial crisis affected the Eurozone accession outlook in Central and Eastern Europe? DNB Working Paper, 253, Amsterdam: De Nederlandsche Bank.

Maarten de Vet, J. (1993). Striving for international competitiveness: lessons from electronics for developing countries. OECD Development Centre Working Paper, 84.

Mačys, G. (2012). The Crisis and Economic Recovery in Baltic States. International Journal of Humanities and Social Science, 2(19), 202-209.

Masso, J. \& Krillo, K. (2011). Labour markets in the Baltic States during the crisis 2008-2009: the effect on different labour market groups. Working Paper Series, Tartu: University of Tartu.

Mayes, S., Pringle R. \& Taylor, M. (2009). Toward a New Framework for Financial Stability. London: Central Banking Publications.

Mundell, R. (2011). The European fiscal reform and the plight of the Euro. Poznan University of Economics Review, 11(1), 7-22.

NBP (2007). Analysis of economic situation in the countries of Central and Eastern Europe in the second quarter of 2007. November, Warsaw: National Bank of Poland. 
Nyberg, L. (2009). The Baltic regional in the shadow of the financial crisis. BIS Review, 105.

Pina, Á. (2011). Structural reforms to reduce unemployment and restore competitiveness in Ireland. OECD Economics Department Working Papers, 910.

Purfield, C. \& Rosenberg, C.B. (2010). Adjustment under a Currency Peg: Estonia, Latvia and Lithuania during the Global Financial Crisis 2008-09. IMF Working Paper, 10/213, Washington D.C.: International Monetary Fund.

Roubini, N. \& Mihm, S. (2010). Crisis Economics: A Crash Course in the Future of Finance. New York: The Penguin Press.

Shiller, R.J. (2008). The Subprime Solution. How Today's Global Financial Crisis Happened, and What to Do About It. Princeton: Princeton University Press.

Smolny, W. (2009). Wage adjustments, competitiveness and unemployment - East Germany after unification. Journal of Economics and Statistics, 229(2-3), 130-145.

Szyszka, A. (2011). Genesis of the 2008 global financial crisis and challenges to the neoclassical paradigm of finance. Poznań University of Economics Review, 11(1), 64-72.

Taylor, J.B. (2009). Getting Off Track. How Government Actions and Interventions Caused, Prolonged, and Worsened the Financial Crisis. California: Hoover Institution Press, Stanford University.

Turner, P. \& Van'tdack, J. (1993). Measuring International Price and Cost Competitiveness. BIS Economic Paper 39 (November), Basel: Bank for International Settlements.

WEF (2007). The Global Competitiveness Report 2007-2008. Geneva: World Economic Forum.

WEF (2008). The Global Competitiveness Report 2008-2009. Geneva: World Economic Forum.

WEF (2009). The Global Competitiveness Report 2009-2010. Geneva: World Economic Forum.

WEF (2010). The Global Competitiveness Report 2010-2011. Geneva: World Economic Forum.

WEF (2011). The Global Competitiveness Report 2011-2012. Geneva: World Economic Forum.

WEF (2012). The Global Competitiveness Report 2012-2013. Geneva: World Economic Forum.

WEF (2013). The Global Competitiveness Report 2013-2014. Geneva: World Economic Forum.

Wolf, H. (2011). Internal devaluation in a monetary union,International Economics and Economic Policy, 8 (1), 3-6.

\section{ABOUT THE AUTHOR}

Dr. Anna Matysek-Jędrych email: anna.jedrych@ue.poznan.pl

Dr. Anna Matysek-Jędrych is Assistant Professor at the Department of International Business and Economics of Poznan University of Economics, Poland. Her main research areas are financial stability, financial and economic crises, monetary policy, central banking and competitiveness in international dimension. She has presented papers at national and international scientific conferences and published multiple articles; most recent ones are chapters of monographs published by IGI Global and ASERS Publishing. She is a Visiting Professor at the School of Business (EscueladeNegocios NovaCaixa Galicia) in Vigo, Spain, member of Academy of International Business (AIB) and Société Universitaire Européenne de Recherches Financières (SUERF). 